\title{
挿管困難をきたした巨大振子様扁桃の手術例
}

\author{
角田 貴継・池田心・伊藤由紀子・小西 邦彦*
}

\section{A Case Report of a Giant Pendulous Tonsil Disturbing Tracheal Intubation}

\author{
Takatsugu Tsunoda, Kokoro Ikeda, Yukiko Ito and Kunihiko Konishi
}

(National Mie Chuo Hospital)

\begin{abstract}
A 3-year-old boy complaining of snoring and dyspnea was admitted to our hospital because of a giant pendulous tonsil in the upper pole of the left tonsil. Tonsillectomy was scheduled on his left side under general anesthesia. However, the big pendulous tonsil disturbed the tracheal intubation, and temporary ventilatory failure occurred. Histological diagnosis revealed tonsil-like tissue. Infantile cases of big pendulous tonsils disturbing tracheal intubation have rarely been reported, and we believe that a sufficient pre-operative plan should be made in order to avoid anesthesiologic trouble in such cases.
\end{abstract}

Key words : giant pendulous tonsil, tracheal intubation, anesthesiologic plan

はじめに

通常みられる扁桃肥大とは異なり，その形態に異常を きたしているものの一つに振子様扁桃がある. 今回，わ れわれは挿管困難をきたすほどの巨大な振子様扁桃の手 術例を経験したので，若干の文献的考察を加えて報告す る.

\section{症例}

症例：3歳, 男児.

主訴：いびき, 呼吸障害, 燕下障害.

既往歴：習慣性扁桃炎の既往なし.

現病歷 : 1999年 1 月頃よりいびき, 睡眠時の呼吸困難 が認められたため, 近医耳鼻科受診, 口蓋扁桃の肥大を 指摘されたが，軽度なためそのまま様子をみていた。し かし次第に症状増悪し, 固形物 (特に肉類)の鰫下が困難 となり同年 7 月 14 日当院小児科受診, 同日当科に紹介さ れた。
局所所見 : 左口蓋扁桃上極付近に茎を有し， 口峡部を ほとんど占有するほどの巨大な腫瘤を認めた（図１）。膿 栓や白苔の付着など扁桃炎の所見はなかった. 右口蓋扁 桃, アデノイドに肥大や腫瘤, 炎症など異常を認めず, 口腔や咽頭粘膜にも異常を認めなかった，その他耳鼻咽 喉頭に異常所見を認めなかった。吸気性喘鳴を認めたが， 心肥大, 肺性心の所見はなかった. 身長 $95 \mathrm{~cm}$, 体重 11 $\mathrm{kg}$ と発育遅延を認めた. 睡眠時無呼吸の精查は行われ なかった。

ほかの腫瘍性病変との鑑別を含め, 1999年 8 月23日に 全身麻酔下にて左口蓋扁桃摘出術を施行した. 全身麻酔 に際し前投薬はブロマゼパムを用い，導入は意識下で 行った.ファイバー下に経鼻捙管を試みたが患者の協力 が得られないため, セボフルレンによる緩徐導入, 経口 挿管に変更した。しかし十分な視野が得られないため挿 管できず，一時的に換気不能となり酸素飽和度が $64 \%$ ま で低下，チアノーゼを呈した。ずぐとセボフルレン濃度 


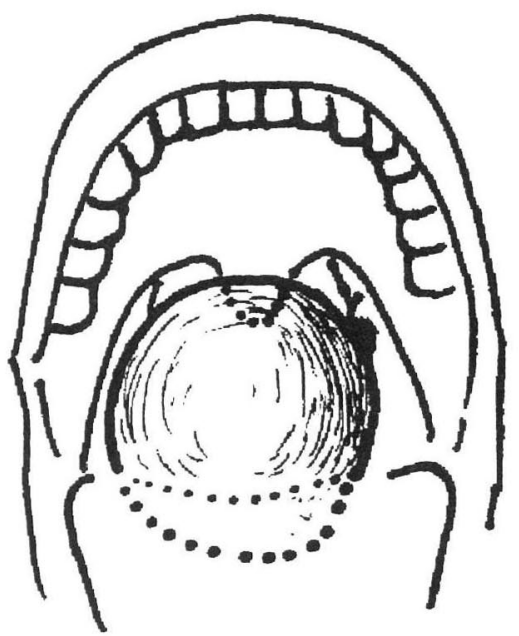

図 1 振子様扁桃の術前の口腔内所見

を下げたところ自発呼吸が回復した。バイタルの安定を 待った後, 再度経口挿管を試みたところ, からうじて声 門が確認され挿管できた。手術所見では，末ずDavis の開口器を用いて術野を確保するも腫瘤が大きく視野が 得難いため，来ず腫瘤部分を母扁桃上極付近にある茎の 部分で切除し，その後母扁桃の摘出を施行した．扁桃は 癒着が軽度で容易に剥離され，出血も少量であった．摘

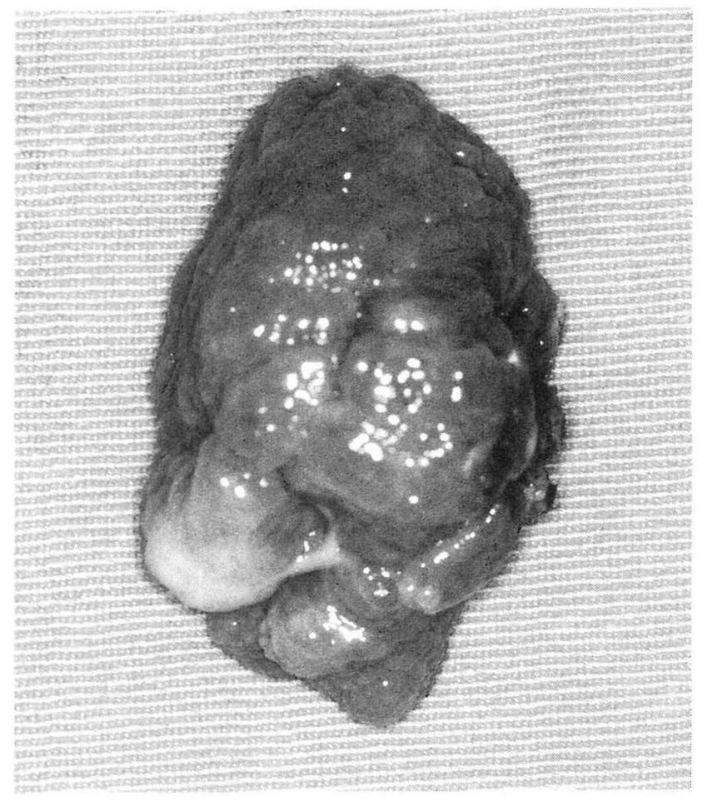

図 2 摘出した振子部分 (大ささ $48 \times 30 \times 28 \mathrm{~mm}$, 重量 $18 \mathrm{~g}$ )

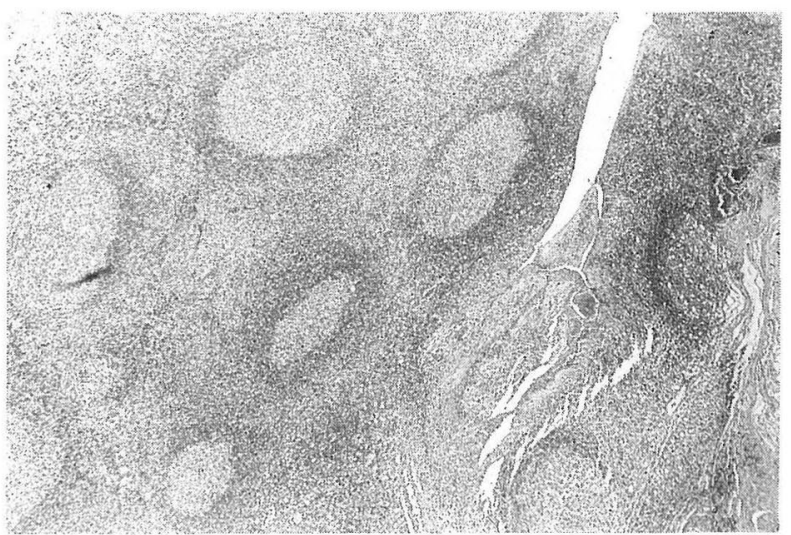

図 3 振子様扁桃の病理組織像 $(\mathrm{HE}$ 染色, $\times 100)$

出した腫瘤の大きさは $48 \times 30 \times 28 \mathrm{~mm}$, 重量は $18 \mathrm{~g}$ で あった(図 2 ). 組織学的には振子部は母扁桃之同じリン パ組織で,リンパ球の浸潤とリンパ濾胞の増生を認めた (図 3 ).

術後, いびき, 呼吸障害, 與下障害は著明に改善し, 8 月 30 日に退院した. 術後 4 カ月目の現在, 経過は良好 であり, 体重も $15 \mathrm{~kg}$ 本で増加した。

\section{考察}

口蓋扁桃の腫脹を呈する主な疾患として，口蓋扁桃肥 大, 扁桃炎, 扁桃周囲膿瘍, 伝染性単核症, 無顆粒球性 アンギーナ，乳頭腫などの良性腫瘍，悪性リンパ腫など の悪性腫瘍等が挙げられる11. 振子様扁桃はそれらに比 べ形態上非常に特徽的であり，その形状から扁桃自体全 体が有茎性となる場合を “真性振子様扁桃”，母扁桃か ら一部が有茎性に突出している場合を“いわゆる振子様 扁桃”之定義され，扁桃に発生した良性交たは悪性腫瘍 が咽頭腔に懸垂している場合を“振子様腫瘤”之呼ぶ2゙. 井口 3) とよると, 振子様扁桃報告例の組織像は, 扁桃組 織 $48 \%$, 乳頭腫 $17 \%$, 線維腫 $5 \%$, 癌腫 $3 \%$, 圭の他 27 \%であるとして㧍り，本疾患の治療にあたっては早期に その振子様扁桃屯含めて母扁桃全摘出し, 摘出後には 病理組織学的検索を行う必要があると思われる.

扁桃之同一組織である振子様扁桃の発生頻度は $1 \sim 3$ 万人に 1 人で，好発年齢は $10 \sim 30$ 歳代，やや男性優位で あり4)，汪とんどが片側性である。発生側の左右差は注 とんどない，佐々木 ${ }^{5)}$ とれば発生部位は口蓋扁桃上極 が圧倒的に多く全体の 8 割弱を占める. 西端ら ${ }^{6)}$ は上極 
より生じるものは20〜25歳にピークを認めるとして抢り， 本例のような小児例は検索し得た範囲内ではまれである.

口蓋扁桃肥大の場合, 睡眠時呼吸障害, 嚥下障害, 吸 気時の鎖骨上窩や胁骨窝の陥没，心肥大，肺性心がみら れることがある．本例も巨大な腫瘤により口峡部を占有 していたといら点では症状として類似するものと思われ る. 今回, 手術後に睡眠時呼吸障害, 嚥下障害が著明に 改善し，体重増加を認めた．年齢が低いといら理由で扁 桃摘出を拒否することがないよう全身の成長発達を考慮 し，必要性があれば手術を行らべきであると思われる7。

本疾患の成因として結論は得られていないが 3 つの説 が今のところ有力視されている2668)。第 1 飞は何らかの 先天的要因のために扁桃萠芽の一つが異常に増殖を続け, 母扁桃組織の退行化傾向と並行せずに成長したといら先 天性奇形説である．第 2 には慢性の炎症性刺激による扁 桃の異型肥大であるといら炎症性刺激説がある。第 3 亿 は腫瘤の増大は慢性刺激によるが発生そのものは先天性 素因によるといら先天性素因十後天性刺激説である．本 例の場合は習慣性扁桃炎の既往がなく，片側性であるこ と，若年発症であること，そして病理組織所見から，先 天性奇形によると考元るのが最も適当ではないかと思わ れる.

また，本例の振子様扁桃は諸家の報告に比べきわめて 大きく，このため麻酔導入時に挿管困難をきたし，挿管 までの間に一時換気不全を呈した．扁桃肥大による挿管 困難は過去に数例の報告があるが910)，麻酔導入に際し ては上気道閉塞に迅速に対応できるよう十分な検討が必 要である．具体的には，ラリンジアルマスクやェアウェ イを事前に準備し，挿管は舌根沈下を防ぐために意識下 で行らなどが挙げられる．術前に気管切開術の可能性に ついても家族に説明し，挿管困難が生じた場合に緊急で 行光るようにして打く必要ああると思われる.

$$
\text { まとめ }
$$

3 歳男児に発症した巨大振子様口蓋扁桃の 1 例を報告 した．片側性で扁桃上極より有茎性に発生して拉り，い びきや呼吸困難をきたすため手術を施行したが，巨大で あったため全身麻酔導入時に挿管困難をきたした．病理 診断は扁桃組織であった。本症が疑われたときにはほか の腫瘍性疾患との鑑別も含め扁桃摘出術を行うが，手術 に際して十分な麻酔計画が必要であると考兄られた。

\section{参考文献}

1) 林 泰弘 : 扁桃の腫脹. 耳喉頭頸 $66: 87 \sim 91,1994$.

2 ) 赤木博文, 西崎和則, 増田 游: 特殊な扁桃肥大. JOHNS $12: 977 \sim 980,1996$.

3 ) 井口晃一: 線維腫像を呈した振子様口蓋扁桃症例. 耳喉 $40: 689 \sim 692,1968$.

4 ) 広重徳子, 荒木真哉 : 珍らしい振子様扁桃(耳管咽頭ひだ より発生)の症例. 耳鼻臨床 $71: 943 \sim 949,1978$.

5 ）佐々木庸一：振子様扁桃の 1 症例. 耳喉 $32: 67 \sim 69,1960$.

6 ）西端慎一, 池上彰博, 高橋広臣 : 口蓋扁桃の振子様腫瘤(振 子様扁桃)の 2 例. 耳喉 $53: 1133 \sim 1136,1981$.

7 ) 工藤典代 : 扁桃肥大とは. JOHNS $12: 973 \sim 976,1996$.

8 ）内藤好宏, 増田 游, 小倉義郎 : 振子様扁桃の 3 症例. 耳 鼻 $34: 1421 \sim 1425,1988$.

9 ) 松田和之, 小崎真也, 金丸聡人, 他 : 巨大舌扁桃により挿 管困難を来した 1 症例。麻酔 $45: 391,1996$.

10）小川 肇, 中村裕二, 内田 博, 他 : 気管内挿管に難淽し た巨大乳頭状扁桃の 1 症例. 臨床麻酔 $17: 1106,1993$.

$$
\left(\begin{array}{l}
\text { 原稿受付 : 平成 } 12 \text { 年 } 3 \text { 月 } 13 \text { 日 } \\
\text { 原稿採択 : 平成 } 12 \text { 年 } 5 \text { 月 } 10 \text { 日 } \\
\text { 別刷請求先 : 角田貴継 } \\
\text { † } 514-8507 \text { 津市江戸橋2-174 } \\
\text { 三重大学医学部耳鼻咽喉科学教室 }
\end{array}\right)
$$

